\title{
Subclover-seeded, fertilized pasture for early weaned lambs
}

\author{
Milton B. Jones $\square$ Montague W. Demment $\square$ Martin R. Dally $\square$ Charles E. Vaughn
}

\begin{abstract}
A 6-year grazing study on subclover pasture at the UC Hopland Field Station indicated that lambs weaned at $\mathbf{4 0} \mathrm{lb}$ made excellent gains. Phosphorus and sulfur fertilization enhanced the gains enough to be profitable. By concentrating lambs on highly productive, well-protected pastures, researchers not only used inputs more efficiently, they also prevented many of the predator losses encountered in nearby, lessprotected pastures.
\end{abstract}

Sheep production on northern California's annual grasslands has decreased sharply over the last three decades, even though ranchers can now significantly improve pasture productivity and quality by seeding and fertilizing legumes. The decrease in sheep production can be attributed to an increase in sheep predation resulting from restrictions on the control of predatory coyotes.

One way to reduce lamb losses is to wean lambs early (at 40 to $50 \mathrm{lb}$ ) and put them on small, high-quality, highly productive pastures where ranchers can maintain better predator control. This approach allows ranchers to concentrate production efforts - such as seeding, fertilization, fencing, and protection - on that part of the flock with highest potential for growth and economic return.

Large areas of annual grasslands in California could be grazed much more productively if they were planted with subclover and appropriately fertilized. $\mathrm{Ni}$ trogen, phosphorus, and sulfur are the three nutrients most commonly deficient in soils. The establishment of subterranean clover (Trifolium subterraneum L.) can greatly enhancesoil nitrogenlevels. Themany varieties now available make it possible for growers to chose the one best adapted to specificlocal environmental conditions. We have seen excellent production from theseclovers when they have been fertilized with phosphorus and sulfur.

This paper reports the cost of establishing a subclover pasture and fertilizing it with phosphorus and sulfur for 6 years, and the lamb gains and dollar returns that result from seeding and fertilization. The study was conducted at the UC Hopland Field Station.

Four varieties of subclover (Mt. Barker, Woogenellup, Nungarin, and Daliak) were sown at $50 \mathrm{lb}$ per acre on 16 acres in October 1982. This sowing rate is much higher than the 10 to $20 \mathrm{lb}$ per acre usually recommended for subclover seed. The high seeding rate established a dense stand of clover early in the study.

Four phosphorus treatments were used: none (P0); $64 \mathrm{lb}$ per acre treble superphosphate applied in October 1982, 1983, 1984, 1985, 1986, and 1987 (P1); 127 lb per acre applied in October 1982 and 1983, plus $61 \mathrm{lb}$ in 1987 (P2); and $254 \mathrm{lb}$ per acre in October 1982, plus61 lbin 1987(P3). Each phosphorus treatment was applied with sulfur (S1) and without (S0). The sulfur was applied at 100 lb per acre in October 1982, and $88 \mathrm{lb}$ per acre in 1984 and 1986. Each of the eight treatments was applied to 1-acre pastures, replicated twice. In addition, three unseeded, unfertilized 1-acre pastures were used for comparison.

The soils were from the Sutherlin series (Ultic Haploxerolls), and had an average Bray\#1 soil test of 11 ppm (moderately high, butstill responsive to phosphorus fertilizer). The measurement for calcium phosphate extractable sulfur was $3 \mathrm{ppm}$ (low). The number of lambs on each pasture was set at the beginning of each year so that the amount of forage per lamb was equal in each pasture.

Targhee lambs were used in 1983 and 1984, and the progeny of Targhee ewes and Suffolk rams were used from 1985 through 1988. Lambs born in late November and
December were weaned and put on the pastures from February 12 to March 10 . The per-lamb costs in veterinary supplies were

seven-way clostridium vaccine:

$\$ 0.128$

three doses fenbendazole:

$\$ 0.62$

two injections BoSe selenium supplement:

salt for 84 days:

$\$ 0.012$

Deccox coccidiostat mixed in the salt the first 32 days on pasture:

The total was $\$ 1.47$ per lamb in 1988 dollars. Multiplied by the number of lambs per acre, this gives the per-acre cost of veterinary supplies (table 1).

The average lamb weighed $47 \mathrm{lb}$ at the beginning of the grazing study. This paper does not consider the cost of producing the lambs to the point of weaning, nor the costs associated with sales or transportation to market. Only the gains the lambs made while on pasture were counted toward the pasture returns.

The number of lambs per acre was proportional to the amount of forage available. This averaged $124 \mathrm{lb}$ of forage per lamb when they were introduced to the pastures. At the beginning of the third 28-day period, the average was $170 \mathrm{lb}$ of forage per lamb. The number of lambs on the unseeded, unfertilized treatmentaveraged5. Averages on the seeded treatments were 7 on unfertilized treatments; 10 on the P1, P2, P3, and $\mathrm{S} 1$ treatments; and 11 on the P1S1,P2S1, and P3S1 treatments.

TABLE 1. Six-year average number of lambs, lamb gain, variable costs, and gross margin per acre for an annual subclover pasture fertilized with phosphorus and sulfur

\begin{tabular}{|c|c|c|c|c|c|c|c|c|c|c|c|}
\hline \multirow[b]{3}{*}{ Treatment } & \multicolumn{7}{|c|}{ Variable costs } & \multicolumn{4}{|c|}{ Gross income } \\
\hline & \multirow[b]{2}{*}{$\begin{array}{l}\text { Number } \\
\text { of lambs }\end{array}$} & \multirow[b]{2}{*}{$\begin{array}{c}\text { Lamb } \\
\text { gain }\end{array}$} & \multicolumn{3}{|c|}{ Amortized costs } & \multirow[b]{2}{*}{$\begin{array}{c}\text { Vet. } \\
\text { supplies }\end{array}$} & \multirow[b]{2}{*}{$\begin{array}{l}\text { Total } \\
\text { costs }\end{array}$} & \multirow[b]{2}{*}{$\begin{array}{l}\text { Lamb } \\
\text { sales }\end{array}$} & \multicolumn{3}{|c|}{ Total } \\
\hline & & & $\begin{array}{l}\text { Clover } \\
\text { estab. }\end{array}$ & $\begin{array}{l}\text { Sulfur } \\
\text { fert. }\end{array}$ & $\begin{array}{l}\text { Phosph. } \\
\text { fert. }\end{array}$ & & & & $\begin{array}{c}\text { Ewe } \\
\text { grazing }\end{array}$ & $\begin{array}{l}\text { gross } \\
\text { income }\end{array}$ & $\begin{array}{c}\text { Gross } \\
\text { margin }\end{array}$ \\
\hline & & $\mathrm{Ib} / \mathrm{ac}$ & & & $\$ \ldots \ldots$ & & & per ac & per ac & $\$$ & perac \\
\hline Unseeded & 5 & 194 & .00 & .00 & .00 & 7.92 & 7.92 & 137.08 & 2.30 & 139.38 & 131.46 \\
\hline CK & 7 & 247 & 29.19 & .00 & .00 & 9.80 & 38.99 & 174.23 & 5.14 & 179.37 & 140.38 \\
\hline S & 10 & 405 & 29.19 & 9.10 & .00 & 15.31 & 53.60 & 285.45 & 11.52 & 296.97 & 243.37 \\
\hline P1 & 10 & 363 & 29.19 & .00 & 15.74 & 14.82 & 59.75 & 256.18 & 10.87 & 267.05 & 207.30 \\
\hline P1S1 & 11 & 435 & 29.19 & 7.26 & 13.44 & 16.17 & 66.06 & 307.08 & 11.88 & 318.96 & 252.90 \\
\hline P2 & 11 & 406 & 29.19 & .00 & 12.86 & 15.43 & 57.48 & 286.39 & 11.53 & 297.92 & 240.44 \\
\hline P2S1 & 11 & 411 & 29.19 & 7.26 & 11.59 & 16.17 & 64.21 & 289.92 & 11.35 & 301.27 & 237.06 \\
\hline P3 & 10 & 368 & 29.19 & .00 & 13.31 & 14.95 & 57.45 & 259.35 & 10.63 & 269.98 & 212.53 \\
\hline P3S1 & 12 & 464 & 29.19 & 7.26 & 12.56 & 17.52 & 66.53 & 327.19 & 12.24 & 339.43 & 272.90 \\
\hline
\end{tabular}




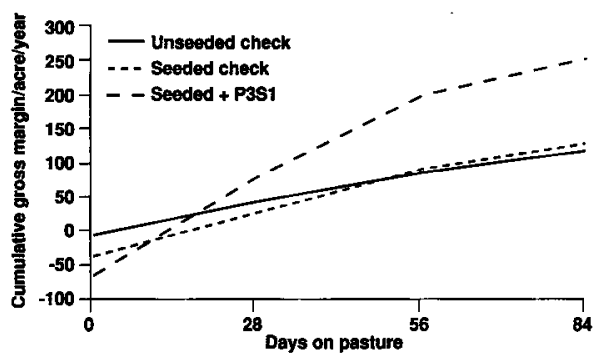

Fig. 1. Cumulative gross margin (in dollars) averaged over 6 years for three treatments.

Lambs remained on the pastures for 84 days each year from 1983 to 1986 . They were removed after 70 days in 1987 and after 56 days in 1988 because of dry pasture conditions. Once the lambs were removed, the pastures were grazed with ewes until 1,000 $\mathrm{lb}$ per acre or less of dry forage remained. This use was measured in sheep days per acre.

\section{Clover establishment}

The cost of establishing the clover, when amortized over 6 years, was $\$ 29.19$ per acre per year. This cost is high because we used a high seeding rate and amortized its cost over only the 6years of ourstudy. Good subclover pastures on the UC Hopland Field Station have existed more than 30 years without renovation. A much less conservative approach would have amortized seeding costs over 30 years, which would have worked out to $\$ 16.82$ per acre, $\$ 12.37$ less per acre than for the 6-year period. These cost differencesare relatively small compared to the gross margins (gross margin = gross income - variable costs).

Some good subclover stands have been established by seeding directly with a range drill without discing and by reducing the seeding rate. However, had we followed the latter procedure we probably could not have successfully established the stand. Despite its high costs, subclover establishment without fertilization increased the gross margin slightly above that of the unseeded pasture - by $\$ 8.92$ per acre per year.

\section{Fertilizer costs and profits}

Applying only sulfur to the seeded pasture biannually increased costs by $\$ 9.10$ per acre per year. This application enhanced clover establishment. Veterinary supplies brought the total costs to $\$ 38.99$ per acre. The sulfuronly treatment increased lamb gain from 247 to $405 \mathrm{lb}$ per acre. Thus, the average peracre profit for the sulfur treatment was $\$ 111.91$ more than for the unseeded check and \$102.99 more than for the seeded-only treatment (table 1).

We applied phosphorus at three rates in October 1982. In that year, there were no significant differences in lamb weight gain per acre between application rates. By the fifth year, all phosphorus treatments had received the same amount of phosphorus one with annual treatment and one with all phosphorus applied the first year. We noted no significant differences among these phosphorus rates and times of application, whether applied with or without sulfur. The amortized cost of annually applied phosphorus differed by $\$ 2.43$ per acre from the amortized cost of phosphorus applied once in 5 years. When phosphorus treatments with sulfur were compared, the difference was only $\$ 0.88$. These values are small compared to the gross margin average for all fertilizer treatments $(\$ 238.07)$, for the seeded treatments only (\$140.38), and for the unseeded-unfertilized treatments $(\$ 131.46)$.

Figure 1 shows the 6-year average cumulative gross margin over the three grazing periods covering 84 days. We obtained the gross margin by subtracting the seeding, fertilizing, and veterinary costs from gross income, which in turn was obtained by multiplying lamb gain per acre by $\$ 0.71$, the average per-pound price obtained for the lambs. An average of 12 days' gain on the fertilized pasture was required for the pastured lambs to break even. The seeded, unfertilized pasture required 16 days' grazing to break even. An average of 18 days' gain was required on the fertilized pastures to reach the same point as the unfertilized and unseeded pasture. The seeded-unfertilized pastures required 56 days of gain for gross margin to reach the same point as the unseeded pastures. Altogether, this indicates that subclover gives little advantage if no fertilizer is applied. It took an average variable cost of $\$ 60.73$ to produce an increase of $213 \mathrm{lb}$ of lamb per acre, or $\$ 0.29$ per pound of lamb gain.

Each year, after the lambs were removed, ewes were placed on each pasture to reduce forage levels. The average number of sheep days per acre required to reduce the forage on offer to a range of 700 to $1,000 \mathrm{lb}$ per acre ranged from 57 days on the unseeded check ( $\$ 2.30$ if valued at $\$ 0.04$ per day) to 304 days on treatment P3S1. Sheep days per acre varied from none in 1986, when forage on offer was about $1,000 \mathrm{lb}$ per acre when the lambs were removed, to an average of 404 days in 1983 . From the seeded check, we obtained 129 sheep days ( $\$ 5.14$ value). The average for all fertilizer treatments was 286 sheep days, or $\$ 11.43$ per year. These data show that significant amounts of forage remained after the lambs were removed, and that seeding and fertilization greatly increased that amount.

Apparently, this forage has relatively little value compared to the amount received from lamb gains in the spring. However, it is important that this type of subclover pasture be grazed in the summer to reduce the forage aftermath to approximately $1,000 \mathrm{lb}$ per acre in order to help maintain clover stands the following year. Young subclover seedlings have a high requirement for light; if the old dry forage is too heavy when the fall rains come, the stand of clover will be reduced for the next year.

\section{Predation control}

In addition to increased lamb gains on fertilized subclover-grass pasture, we found coyote losses were dramatically less for this study than for the general flock on the Hopland Field Station. In 4 years of the study, thestudy lost nolambs to coyotekills. In the other 2 years of the study, lamb losses were three and one. A total of four lambs were lost out of the more than 1,200 used in the study, an extremely low rate. These reduced losses probably resulted from greater human presence and tighter fences for the lambs.

The study pastures were one-half mile from station headquarters and were bordered by a ranch road. Because the pastures were monitored daily, the coyote's entry place was easily found when a lamb was killed. The coyote was quickly trapped, and thelambkillingstopped. Losses from groups of ewes and lambs more widely scattered in the surrounding pastures have been at least $10 \%$ per year, and often greater.

\section{Conclusions}

Under the study conditions, fertilizing subclover pasture with phosphorus and sulfur was very profitable. The 6-year average of all phosphorus and sulfur treatments increased lamb gains by $213 \mathrm{lb}$ per acre per year at an average cost of $\$ 60.73$, or at a lamb cost of $\$ 0.29$ per $\mathrm{lb}$. This resulted in profit from lamb gains and summer grazing by ewes of $\$ 92.32$ per acre per year over the unseeded, unfertilized treatment. Averaged over the 6 years of the study, the lambs gained enough in the first 12 days on pasture each year to pay for the seeding and fertilizer. There was little profit in seeding subclover without fertilizing, but there was enough increase in lamb gain to at least cover the seeding costs.

Lamb losses to coyotes were much lower on highly productive pastures that were tightly fenced than on the more scattered general flock.

Milton B. Jones is Agronomist, UC Hopland Field Station; Montague W. Demment is Associate Professor, Department of Agronomy and Range Science, UC Davis; and Martin R. Dally and Charles E. Vaughn are Staff Research Associates, UC Hopland Field Station.

We thank the Potash and Phosphate Institute for the grant and encouragement that made this study possible, the UC Hopland Field Station staff for essential assistance, and Rhone-Poulenc, Inc., for donating Deccox used for the control of coccidiosis. 


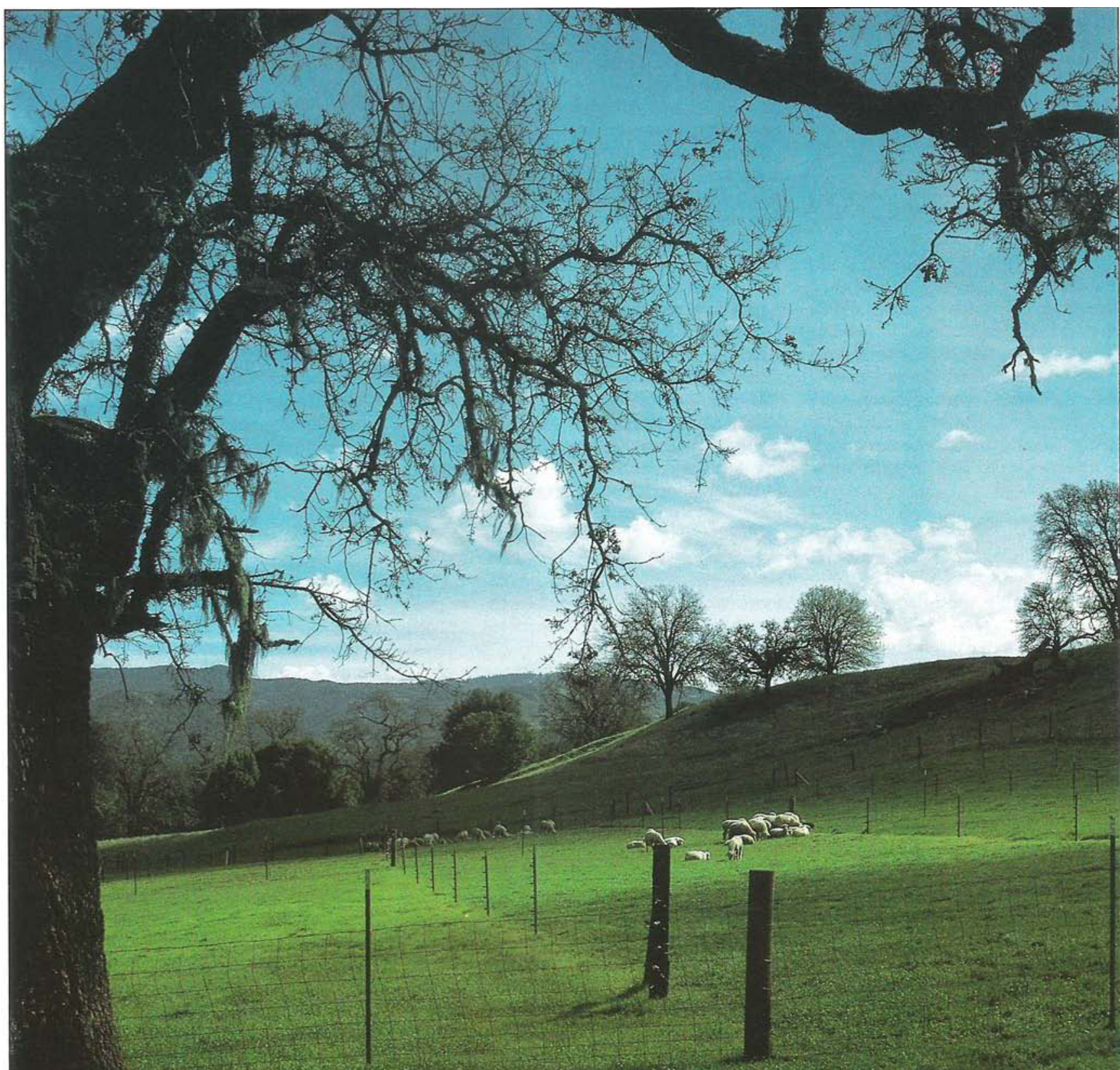
tilization, and also because the pastures were more closely monitored, and thus better protected from predators. (See article, page 38.) 